\title{
Gender, Age and Faculty Differences in Learning Practices among Undergraduates at the National University of Lesotho: Way Forward to Improve Learning
}

\author{
Tebello Violet Tlali ${ }^{\circledR}$, Som Pal Baliyan* ${ }^{*}$ \\ National University of Lesotho, Roma, Lesotho \\ Email: *baliyansom@gmail.com
}

How to cite this paper: Tlali, T. V., \& Baliyan, S. P. (2021). Gender, Age and Faculty Differences in Learning Practices among Undergraduates at the National University of Lesotho: Way Forward to Improve Learning. Creative Education, 12, 2253-2276. https://doi.org/10.4236/ce.2021.1210171

Received: August 18, 2021

Accepted: October 9, 2021

Published: October 12, 2021

Copyright $\odot 2021$ by author(s) and Scientific Research Publishing Inc. This work is licensed under the Creative Commons Attribution International License (CC BY 4.0).

http://creativecommons.org/licenses/by/4.0/

\begin{abstract}
This quantitative study analysed gender, age and faculty differences in the learning practices and other pertinent factors as perceived by the undergraduate students at the National University of Lesotho (NUL). The quota sampling method was used to select 312 students $(n=312)$ from the seven faculties. Adopting the constructivism theory of learning, a validated and reliable questionnaire was constructed for data collection through a survey. The questionnaire had thirty seven items on the four categories of learning practices: classroom practices, studying practices, assessment practices and academic integrity practices. Fifteen items focused on the pertinent personal factors and the institutional factors. All the items were measured on a five point Likert's Scale. Data was analysed through statistical tools of Independent t-test and Analysis of Variance. Students perceived all the four learning practices above the mean level. Classroom practices and studying practices were perceived to be the highest and lowest learning practices, respectively. Academic integrity practice had a gender difference in students' perception while age difference was determined in studying practices. Neither age nor gender difference was determined in students' perception towards either the personal or the institutional factors pertinent to learning. Students perceived three learning practices differently: assessment practices, studying practices and academic integrity practices. Studying practices and assessment practices were perceived the lowest by students in Science and Technology Faculty while academic integrity practices were at the lowest in the health sciences faculty. The study recommends that these faculties improve on these learning practices in order to improve learning among the undergraduates at the university.
\end{abstract}




\section{Keywords}

Learning Practices, Learning Improvement, Gender Difference, Students' Perception, University Education

\section{Introduction}

Education should fulfil the acquisition of all the parameters of quality education. These can only be achieved through quality teaching and learning. Any initiative that is intended to improve the quality of education needs to be firmly focused on improving teaching and learning (O'Leary \& Wood, 2019). While the countries around the world have made great strides in increasing access to education, much of it is still of low quality and low learning outcomes have been reported in Africa, Latin America and other parts of the world (Bruns \& Luque, 2014; Eddy-Spicer, Ehren, Bangpan, Khatwa, \& Perrone, 2016). Therefore, the current international debate on education is centered on the notion of providing quality education to the learners, including those who face the barriers to learning (Dlouhá \& Pospiśilová, 2018). The quality of teaching is preponderant for learning in order to achieve high performance. Several components of teaching and learning contribute negatively to the teaching effectiveness which ultimately influences students' learning in higher education institutions negatively (Baliyan \& Moorad, 2018). Students' learning is the key research area in higher education. It deals with the learning approaches and the factors that influence them (Tight, 2014). Higher education is increasingly entrusted with the responsibility to produce autonomous and critical thinkers, versatile experts and life-long learners in their fields of study. In order to achieve this objective, higher education institutions are expected to nurture deep learning among their students (Asikainen \& Gijbels, 2017). The National University of Lesotho (NUL) is the largest higher education provider in Lesotho. It accommodates approximately 10,000 students (NUL, 2018). This figure accounts for over $50 \%$ of the student population in higher education in the country. As is the case with most higher education institutions, NUL also aspires to create an environment that nurtures deep learning among the students as it is highlighted in the NUL strategic goal to transform the institution into "a university of choice providing high quality education" (NUL, 2015: p. 19). However, the achievement of this strategic goal is questionable and far from achievement. Like other universities, NUL faces some challenges in achieving its stated goals (Chatterton, 2020; Iannone, Czichowsky, \& Ruf, 2020; Evans \& Popova, 2016). Mokhethi, Malunga, \& Thetsane (2019) identified students' satisfaction dimensions. These are the university environment and attractiveness as well as instructor and programme factors. They indicate that the majority of students are not satisfied with the university services. Learning may be compromised by the institutional factors during the teaching and learning practices at NUL (Tlali \& Jacobs, 2015). Quality higher 
education can only be achieved by ensuring a shift from surface to deep learning. Currently, deep learning at NUL may be jeopardised by poor teaching and inadequate learning practices as well as personal and institutional factors (Tlali, 2019b).

NUL is not the only a public university but it is also the largest higher education provider in the country. However, the quality of teaching and learning has been found questionable. Teaching and learning practices are considered crucial for improving the quality of education. It is thus imperative for the university to take steps to address the issues related to the quality of teaching in order to improve learning and to serve its mission and vision of offering quality higher education in the country. Teaching and learning are complimentary to each other and have reversal influence. Considering the prevailing situation of the teaching and learning practices at the university, it is crucial to analyse the learning practices as a way forward for improving the quality of education at the university. Therefore, this study aimed to analyse the learning practices and pertinent factors as perceived by the students at NUL. The study has two objectives:

1) To determine the differences in the learning practices as perceived by the students' gender, age and faculty at NUL.

2) To determine the differences in pertinent factors to learning practices as perceived by the students' gender, age and faculty at NUL.

To achieve these objectives, the following research questions were answered

1) Are there gender, age and faculty differences in the learning practices as perceived by the students at NUL?

2) Are there any differences in pertinent factors to learning practices as perceived by the students' gender, age and faculty at NUL?

The study had the following hypotheses:

1) There are gender, age and faculty differences in the learning practices as perceived by students at NUL.

2) There differences in pertinent factors to learning practices as perceived by the students' gender, age and faculty at NUL.

\section{Literature Review}

Literature reviewed is presented in the subsections as follows.

\subsection{Theoretical Framework}

Learning theories are valuable to educators as help to understanding what affects the learning of the students. The three theories of learning: behaviorism, cognitivist and constructivism theories (Alzaghoul, 2012). They differ from each other in their features from an instructional design perspective (Ertmer \& Newby, 2013). This study is anchored within the constructivist theory which considers that individuals play an active role in constructing their own knowledge about their experiences and circumstances (Croy, 2018; Jaiwal, 2019). Constructivism is a learning theory which affirms that knowledge is best gained through a proc- 
ess of action, reflection and construction (Brau, 2020). Thus, it explains how knowledge is created and how people learn. This theoretical perspective is associated with metaphors of building which are used to illustrate how learners acquire knowledge. Derry (2018) concurs that constructivism adopts a "building blocks" approach to knowledge construction. The proponents of constructivism include philosophers such as John Dewey, Jean Piaget and Lev Vygotsky. From a John Dewey's point of view, constructivism recognises that knowing is not a passive phenomenon but it is an active building process (Chang, 2018). Unlike other positivistic theories which perceive the learner as merely a recipient of an external stimulus, constructivism accentuates the significance of action as well as the active nature of learning (Omodan, 2019; Chatterton, 2020). This view is captured in John Dewey's well-known principle of "learning by doing". Accordingly, the learners are not expected to wait passively and inactively for the external stimuli. Rather, it is anticipated that the learners also act upon the surroundings and their own experiences. This implies that a mutual interaction between the learner and the environment forms the foundation upon which learning, thinking and knowing can be understood (Omodan, 2019; Spiegel, 2020).

Constructivism upholds several tenets for learning. It proposes that firstly the learners construct a new understanding on the basis of their existing schema; Secondly, that collaboration among the learners triggers cognitive processes that lead to knowledge construction and reconstruction; thirdly, that exploration heightens the discovery of new knowledge; fourthly, that learning through designing excites the learners as they put their own ideas into practice (Ah-Nam \& Osman, 2017). Drawing from the aforementioned tenets, it is observed that constructivism regards the learner as a responsible partner in the creation of new knowledge while the teacher's role is to scaffold the learner and become the coexplorer of new knowledge (Croy, 2018; Chatterton, 2020). Ultimately, these processes lead to the achievement of some equilibrium in the cognitive structure (Van Kesteren \& Meeter, 2020). The theory of constructivist learning is vital to understanding how students learn and, thus forms the foundation for this study.

\subsection{Students' Learning Approaches}

A learning approach is defined as a personal attribute that influences the way a student interacts with information, peers as well as teachers and the way in which they participate in the learning experience. This concept denotes the preferences and distinctive ways in which students acquire and process information during the learning process (Corbin, 2017; Wongwatkit, Panjaburee, Srisawasdi, \& Seprum, 2020). Marton and Saljo (1976) identified and distinguished between deep and surface learning. According to Marton and Saljo, the students' ability to apply high order cognitive processes is ascribed to the deep learning approach while the use of lower order cognitive processes is linked to the surface learning approach. 
Cetin (2016: p. 16) highlights that the surface approach to learning is related to

the intention of finishing a task without putting much effort in it and seeming to fulfill requirements, leading to the use of lower cognitive activities even if the task requires higher level activities. The surfaceapproach is seen as cutting corners.

Students who use the surface approach to learning are inclined to superficially peruse the learning material, thereby rendering learning to merely a reproduction activity (Richardson, 2013). A surface learning approach leads to the attainment of fragmented and formulaic memorisation of information. The fragmented details are passively and rote learned to be simply reproduced when required (Asikainen \& Gijbels, 2017; Ellis \& Bliuc, 2019; Hailkari et al., 2021). The sign of surface learning includes presenting a verbatim recollection of information without constructing any substantial argument, as well as failing to construe or exhibit a critical reflection of such information. Furthermore, it becomes difficult for the student to even apply the information in new situations (Arquero, Fernandez-Polvillo, Hassall, \& Joyce, 2015; Asikainen \& Gijbels, 2017; Postareff et al., 2018).

Deep learning is often described in contrast to its antonym surface learning. Cetin (2016: p. 21) defined the deep approach to learning as

a directed need to complete a task in an appropriate and meaningful way, which leads to using the most appropriate cognitive functions for working on a task. The use of deep approach creates positive feelings such as interest, feeling important, challenge, and even exhilaration.

Typically, deep learning originates from the learners' intrinsic motivation (Baeten, Dotchy, Struyven, Parmentier, \& Vanderbruggen, 2016; Iannone et al., 2020) which is further driven by the learner's desire to use high cognitive skills in order to complete the task meticulously (Tlali, 2019a). It also refers to the capacity to establish how the distinct parts of learning material converge to form a bigger picture, as well as to provide related evidence (Postareff, Mattsson, \& Parpala, 2018). Students who adopt a deep approach to learning are able to achieve knowledge which is highly structured and coherent (Chatterton, 2020; Iannone, Czichowsky, \& Ruf, 2020). This results in the development of relational responses to tasks, long-term retention as well as the ability to apply knowledge to new and unique situations (Asikainen \& Gijbels, 2017). Thus, students are able to develop and apply reflective and critical thinking skills and can grasp the underlying meaning and purpose of tasks in relation to the course learning outcomes (Poondej \& Lerdpornkulrat, 2016; Ellis \& Bliuc, 2019; Hailkari, Virtanen, Vesalainen, \& Postareff, 2021). In order to enhance deep learning, the teaching and learning approaches must be student-centered (constructivist) in nature (Baeten et al., 2016). They should also be guided by the learning taxonomies and be constructively aligned to the learning outcomes (Chatterton, 2020). 
The learning approach, whether surface learning or deep learning comprises several practices such as classroom practices, studying practices, assessment practices and academic integrity practices. Classroom practices involve multiple activities and interactions between the teacher and students. The process can be diverse in its formats and structures, and its effectiveness can be influenced by internal and external factors (Li \& Oliveira, 2015). Classroom practices include supportive lesson practices, effective lesson management, well organized lessons, clear, objective and focused lessons, student engagement quality questioning assessment and feedback practices (Kington et al., 2012). Assessment is an integral part of an educative process as it forms the background to the formulation, monitoring and adjusting the objectives of the programmes. Hence the practice of fair assessment is a prerequisite to obtaining success in learning and quality education (Areekkuzhiyil, 2019). Assessment helps in the development of teaching and learning processes as it enables teachers and students to draw inferences from the information obtained and to act accordingly (Black \& Wiliam, 2018). Brown et al. (2009) highlighted that assessment practices improve teaching and diagnose students' learning needs. Promoting authenticity and academic integrity in assessment should be the priority for educational institutions as it does not only lay the foundation for high academic standards and practice but also authenticates assessments and academic integrity and enriches students with appropriate learning and skills (Sotiriadou, Logan, Daly, \& Guest, 2020). The attainment of knowledge and skills is the central goal of all learning activities. The prerequisites for successful student learning require, among others, alignment between research and teaching practices and learning designs. To do so, one needs to have an insight into the learning practices adopted by the students. The barriers to student learning are structural, institutional, cultural and pedagogical (Børte, Nesje, \& Lillejord, 2020). As the male and female students of various age groups are offered courses in different faculties, it is also important to observe the studies on the gender and age differences in the learning practices.

\subsection{Gender Differences in Learning Practices}

Studies have been conducted to determine whether gender is a factor in adopting a particular learning approach or not. Corbin (2017) reports that male and female students learn differently and that males are more individualistic. They may prefer to work and learn on their own whereas females are more collaborative. Aguillon, Siegmund, Petipas, Drake, Cotner, and Ballen (2020) indicate that males demonstrate higher self-efficacy than their female counterparts in studying the science subjects. Contrarily, Chen, Yang and Hsiao (2016) determined that females score higher on the appreciation of course design in Mathematics while males score higher on system quality. Duff and Mladenovic (2015) established that female students scored significantly higher marks than males for adopting the surface approach in Accounting. On the contrary, Mahmud and Nur (2018) find that gender affects the learning approaches. Balam (2015) concluded that 
there was no statistically significant difference between male and female students in their learning approaches while Khong, Hassan, \& Ramli (2017) do not find any significant difference in the learning approaches between the male and female students. However, females do obtain overall higher scores in learning English and Spanish.

\subsection{Age Differences in Learning Practices}

The age of students has a significant effect on the adoption of a particular learning approach. Richardson (2013) established that the scores increased with the students' increase in age, when deep learning is adopted. Similarly, Cetin (2016) determined a significant positive relationship between students' age and the learning approaches while mature students showed higher self-efficacy towards the learning approach than their junior counterparts. On the contrary, Wahlheim, McDaniel and Little (2016) determined that older adults were largely unable to grasp the correct rules due to their learning and memory impairment hence they resorted to rote learning which is associated with the surface approach. It was concluded that younger generations perform better than the older ones in rules learning.

\subsection{Faculty Differences in Learning Practices}

Previous research indicates that the discipline of study influences students' approaches to the learning process? (Baeten et al., 2016). Vermunt and Donche (2017) concur that learning approaches that students adopt can be linked to disciplinary differences. In the creation of favourable environments for the facilitation of the deep approach to learning, several studies favoured Human Sciences or the Arts subjects (such as social sciences, psychology, language/literature, health, politics and philosophy) as opposed to the Natural Sciences and Economics (Baeten et al., 2016). Webber (2012) adds that the faculties which teach courses that are hands-on find it easier to integrate learner-centered methods and to promote deep learning. Webber (2012) further indicates that faculties in the more theoretical disciplines turn out to use less learner-centered approaches than those in the comparatively hands-on disciplines. However, Parpala, Lindbloem-Ylanne, Komulainen, Litmanen and Hirsto (2010) confirmed that soft disciplines (Arts) score higher on deep approaches than the hard disciplines (Natural Sciences). Nonetheless, Parpala et al. (2010) highlighted that the effect sizes were rather low. Hence, further research is recommended in order to illuminate the complex correlation between students' learning approaches and the various disciplines if any.

\subsection{Factors Affecting the Learning Practices}

The adoption of a particular learning approach, either deep or surface, is not innate. The learning environment plays a pivotal role in the adoption of a particular learning approach (Uiboleht, Karm, \& Postareff, 2018). The learning envi- 
ronment refers to the pedagogical, social and psychological contexts within which learning occurs. Poondej and Lerdpornkulrat (2016) concur that students' approaches to learning can be influenced by their personal attributes as well as the learning contexts. This view is further underscored by Baeten et al. (2016) and Postareff et al. (2018) who indicate that constructivist environments that scaffold student-centered learning methods tend to promote deep learning. Such environments allow students to learn meaningfully by actively engaging them to interpret and apply information based on their prior knowledge as well as by and allowing then to participate in the process of actively constructing knowledge (Asikainen \& Gijbels, 2017; Uiboleht et al., 2018).

Other factors that affect deep learning include teaching and assessment practices, students' factors such a motivation, as well as other institutional factors (Tlali, 2019b). Nurna and Rudi (2020) determined that the factors that can affect learning among the students are derived from internal and external factors. Internal factors are personal factors which depend on the ability of an individual to start and accomplish an activity. Psychological factors are internal and they originate from a person. Psychological factors are innate from birth. They include interests, talents, intelligence (Chaika, 2020). External factors come from the outside environment and may have either positive or negative impact on internal factors, depending on one's social environment. The social environment that is not conductive can make internal factors decrease their impact. This also has an impact on student learning and achievement.

Motivation is one of the factors that have a significant bearing on learning. It can either be intrinsic or extrinsic (Baeten et al., 2016; Iannone et al., 2020). Personal and environmental factors affect a student's confidence level and determination in spirit in a school environment. Those factors can subsequently affect a student's learning behaviour and performance at school. Personal factors such as motivation, whether it is intrinsic or extrinsic, influence the learning of students. Intrinsic motivation originates from students' determination to do well. When students are motivated, they make their studies a priority and resist other personal temptations that may jeopardise their learning (Baeten et al., 2016). Extrinsic motivation may originate from the educator or the teaching and learning environment. For instance, some educators may exhibit lack of interest in their students through their explicit lack of passion and professionalism (Iannone, Czichowsky, \& Ruf, 2020). Institutional factors are external factors. They may also promote or adversely affect learning. These include the availability of teaching facilities as well as the establishment of a clear teaching, learning and assessment policy. Monitoring mechanisms for the teaching, learning and assessment practices also play a critical role in the achievement of learning (Tlali, 2019a). Institutional culture and factor also play a fundamental role in improving learning. Institutional culture that is positive and cohesive enhances excellence in teaching and learning. Conclusively, the adoption of a particular learning approach is determined by various contextual fac- 
tors including those which originate from the learners themselves (Asikainen \& Gijbels, 2017; Zhao et al., 2018; Hailkari et al., 2021) or emanate from the institution.

There are studies on student learning and teaching practices in higher education (Lumpkin, Achen, \& Dodd 2015). However, researchers identify pockets of innovative teaching practices in higher education (Sinclair \& Aho 2018; White et al., 2016), despite the frequent calls for change from students, researchers, policymakers and university leaders and a few signs of continuous and large scale improvements. Students' learning practices are equally important in teaching and it is important to explore their perceptions on their learning practices. To better understand the inertia in the development of teaching practices and explicate the complex and compound reasons behind it, we explore the barriers to student active learning. The literature has reflected contradictory and inconclusive findings on the relationship between the age, gender, faculty and learning approaches. Duy, Binh, and Giang (2021) found no difference in students' motivation for learning between students' gender, age and field of study. Pinto, Bigozzi, Vettori, and Vezzani (2018) highlighted the importance of different learning approaches and recommended that the learning practices should be analyzed for specific subject academic fields.

The literature reviewed has reflected that a good work has been done on the age, gender and faculty differences in students learning practices. Most of such research have been focusing in developing countries and, have highlighted the inconsistent and diverged findings. Further, universities have several faculties which offers various courses to different age group of students and, it is obvious that there are difference in the learning practices and their pertinent factors. The researcher could not find any such published work in the context of Sub Saharan African Countries, particularly in Lesotho. Therefore, this study was conducted to analyse gender, age and faculty differences in the learning practices and other pertinent factors as perceived by the undergraduate students at the National University of Lesotho (NUL).

\section{Methodology}

\subsection{Research Design}

This study adopted a quantitative survey and descriptive research design. A quantitative survey research is used to investigate the views or opinions of the respondents and to explore and describe the factors of influence on the population of interest (Creswell, 2017). Surveys are useful in gathering information on the general attitudes, opinions or certain behaviours and are considered fast and cost effective (Creswell \& Creswell. 2017). This study aimed to analyse the learning practices and pertinent factors as perceived by the students and, the quantitative descriptive survey research design was found suitable as it encompasses measurement procedures that involve gathering factual information, asking questions or perceptions from respondents (Nardi, 2018). 


\subsection{Population and Sampling}

Undergraduate students enrolled in the seven faculties at NUL $(\mathrm{N}=6402)$ constituted the population for this study. Considering the possible differences in the learning practices among the students in different subjects and faculties, a Quota sampling was adopted to ensure the representation of students from all the faculties as it is a non-probabilistic equivalent of stratified random sampling (Acharya, Prakash, Saxena, \& Nigam, 2013; Toylan, Semerciöz, \& Hassan, 2020). Quota sampling strives to represent significant characteristics of the wider and diverse population with specific characteristics (Bhardwaj, 2019). Considering a Quota of 5\% of the students to be a representative sample from each faculty, 312 students ( $\mathrm{n}=$ 312) from the seven faculties were sampled for this study (Table 1).

\subsection{Instrumentation for Data Collection}

Based on the literature and interviews with the lecturers and students at the university, a questionnaire was constructed to solicit information from the respondents. The questionnaire comprised three sections. The first section sought demographic information of the respondents. The second section comprised 36 items on the four groups of learning practices: classroom practices, assessment practices, academic integrity practices and studying practices. The third section had 15 items on the two pertinent factors to the learning practices: the personal and institutional factors. All the items in sections two and three were measured on a five point Likerts' scale: $1=$ strongly disagree, $2=$ disagree, $3=$ neutral, $4=$ agree and $5=$ strongly agree. The validity of the questionnaire was accomplished by an expert review panel of experts in educational management and educational research. As a measure for ensuring reliability of the questionnaire, Cronbach's alpha reliability coefficients for the three learning practices and two pertinent factors were calculated which ranged between 0.714 and 0.871 (Table 2) and, thus were found to be greater than the acceptable minimum of 0.70 (Taber, 2018).

Table 1. Sampling of Male and Female students in the Faculties at the National University of Lesotho.

\begin{tabular}{ccccccc}
\hline \multirow{2}{*}{ FacultylGender } & \multicolumn{2}{c}{ Female } & \multicolumn{2}{c}{ Male } & \multicolumn{2}{c}{ Total } \\
\cline { 2 - 7 } & $\mathbf{N}$ & $\mathbf{n}$ & $\mathbf{N}$ & $\mathbf{n}$ & $\mathbf{N}$ & $\mathbf{n}$ \\
\hline Agriculture & 138 & 7 & 205 & 10 & 343 & 17 \\
Education & 1086 & 50 & 627 & 30 & 1713 & 80 \\
Health Sciences & 285 & 15 & 223 & 10 & 508 & 25 \\
Humanities & 522 & 25 & 140 & 10 & 662 & 35 \\
Law & 198 & 10 & 147 & 10 & 345 & 20 \\
Science and Technology & 204 & 10 & 522 & 25 & 726 & 35 \\
Social Sciences & 1252 & 60 & 853 & 40 & 2105 & 100 \\
Total & 3685 & 177 & 2717 & 135 & 6402 & 312 \\
\hline
\end{tabular}


Table 2. Reliability Coefficients of learning practices and their pertinent factors.

\begin{tabular}{ccc}
\hline Construct of Learning Practice & Number of Items included & Reliability Coefficient \\
\hline Classroom practices & 10 & 0.859 \\
Assessment practices & 7 & 0.801 \\
Academic integrity Practices & 5 & 0.738 \\
Studying practices & 15 & 0.871 \\
Personal factors & 11 & 0.812 \\
Institutional factors & 4 & 0.714 \\
\hline
\end{tabular}

\subsection{Data Collection and Analysis}

A survey was conducted to collect data using a valid and reliable questionnaire. The lecturers in the faculties assisted the researchers with the administration of the questionnaires. Students were asked to respond to the questionnaire and the copies were collected by the lecturers immediately after completion by the students. Altogether, 300 students responded to the questionnaire. Descriptive and differential statistics were used for data analysis whereby the Independent $t$-test and a One way analysis of variance were employed. A Frequency analysis was employed to obtain the descriptive statistics of the participating students. An Independent $\mathrm{t}$-test was used to determine the difference in the learning practices among the students for their gender and age groups. A One way analysis of variance was used to determine the difference in the learning practices adopted by the students in different faculties. A detailed procedure of the data analysis for each of the research questions is provided under the results and discussion.

\section{Results and Discussion}

\subsection{Demographic Information of the Participating Students}

Out of a sample of 312 students, 300 completed the questionnaire. Demographic information of the participating students is presented in Table 3. The female students who participated in this study were slightly more (51.7\%) than the male students (47\%) in number. The majority of students (60.6\%) were less than the 24 year olds. Four and ten students did not indicate their gender and age, respectively and were excluded from the respective data analysis. The Education faculty was the largest faculty had the highest number of students (26.3\%) while the lowest (6.3\%) number of students represented the Science and Technology faculty (Table 3 ).

\subsection{Student's Perceptions towards Learning Practices and the Pertinent Factors}

In this study, learning practices included the classroom practices, assessment practices, academic integrity and studying practices while personal factors and institutional factors were treated as the factors that influence the learning practices. The mean and standard deviation for the learning practices and their per- 
tinent factors are presented in Table 4.

Though all the four categories of the teaching practices were perceived above the mean level $(M=3.00)$, the highest and the lowest learning practices were determined to be the classroom practices $(\mathrm{M}=3.97, \mathrm{SD}=0.424)$ and studying practices $(M=3.30, S D=0.447)$, respectively. It highlighted that studying practices need to be improved in order to improve the learning process. Similar findings were reported by Chatterton (2020) indicated that studying practices can be improved to boost learning among the students. Institutional factors were found to be lower than the mean $(\mathrm{M}=2.897, \mathrm{SD}=2.269)$. This finding contradicts the findings of Henderson, Selwyn and Aston (2017) and, Picton, Kahu and Nelson (2018). The contradiction may be interpreted through the fact that

Table 3. Demographic information of students $(n=300)$.

\begin{tabular}{|c|c|c|}
\hline Demographic Variable & $\mathbf{N}$ & $\%$ \\
\hline \multicolumn{3}{|l|}{ Gender } \\
\hline Female & 155 & 51.7 \\
\hline Male & 141 & 47.0 \\
\hline Gender not identified & 4 & 1.3 \\
\hline \multicolumn{3}{|l|}{ Age } \\
\hline$\leq 24$ years & 182 & 60.6 \\
\hline$\geq 25$ years & 108 & 36.0 \\
\hline Age not identified & 10 & 3.3 \\
\hline \multicolumn{3}{|l|}{ Faculty } \\
\hline Agriculture & 30 & 10.0 \\
\hline Education & 79 & 26.3 \\
\hline Health Sciences & 25 & 8.3 \\
\hline Humanities & 23 & 7.7 \\
\hline Law & 20 & 6.7 \\
\hline Science and Technology & 19 & 6.3 \\
\hline Social Sciences & 104 & 34.7 \\
\hline
\end{tabular}

Table 4. Mean and Standard Deviation of student's perceptions towards the learning practices and the pertinent factors $(n=300)$.

\begin{tabular}{ccc}
\hline Construct & M & SD \\
\hline Classroom practices & 3.97 & 0.424 \\
Assessment practices & 3.77 & 0.585 \\
Academic integrity practices & 3.62 & 0.774 \\
Studying practices & 3.30 & 0.447 \\
Personal factors & 3.26 & 0.558 \\
Institutional factors & 2.89 & 2.269 \\
\hline
\end{tabular}


institutional factors differ from institution to institution and, in turn, intervene in students learning differently (Saar, Täht, \& Roosalu, 2014).

\subsection{Differences in Students' Perceptions towards Learning Practices}

Findings on the gender, age and faculty differences in students' perceptions towards learning practices are presented in the subsections as follows.

\subsubsection{Gender Differences in Students' Perceptions towards Learning Practices}

An Independent t-test was employed to determine gender differences in students' perceptions towards the learning practices whereby the gender of students was used as an independent variable and the learning practices were treated as dependent variables. The results of the Independent t-test are presented in Table 5.

Academic integrity practices were the only learning practices that had a significant gender difference in students' perceptions towards $(\mathrm{t}=2.668, p=0.007)$ and no gender difference for the other leaning practices was determined (Table 5). Further, female students perceived academic integrity practices higher $(\mathrm{M}=$ 3.73; $\mathrm{SD}=0.709)$ as compared to the male students $(\mathrm{M}=3.49$; $\mathrm{SD}=0.824)$. It indicated that female students were perceived to have higher academic integrity in their learning and that male students need to improve on academic integrity

Table 5. Difference in male and female students' perceptions towards the learning practices $(n=296)$.

\begin{tabular}{|c|c|c|c|c|c|}
\hline \multirow{2}{*}{ Gender } & \multicolumn{5}{|c|}{ Classroom practices } \\
\hline & $n$ & $M$ & $S D$ & $t$ & $p$ \\
\hline Female & 155 & 3.95 & 0.439 & & \\
\hline Male & 141 & 4.00 & 0.406 & 0.924 & 0.356 \\
\hline Overall & 296 & 3.97 & 0.242 & & \\
\hline Gender & \multicolumn{5}{|c|}{ Assessment practices } \\
\hline Female & 155 & 3.79 & 0.563 & & \\
\hline Male & 141 & 3.73 & 0.601 & 0.909 & 0.364 \\
\hline Overall & 296 & 3.76 & 0.582 & & \\
\hline Gender & \multicolumn{5}{|c|}{ Studying practices } \\
\hline Female & 155 & 3.25 & 0.447 & & \\
\hline $\mathrm{M}$ ale & 141 & 3.33 & 0.446 & 1.499 & 0.134 \\
\hline Overall & 296 & 3.29 & 0.448 & & \\
\hline Gender & \multicolumn{5}{|c|}{ Academic integrity practices } \\
\hline Female & 155 & 3.73 & 0.709 & & \\
\hline Male & 141 & 3.49 & 0.824 & 2.688 & $0.007^{\star}$ \\
\hline Overall & 296 & 3.62 & 0.774 & & \\
\hline
\end{tabular}

${ }^{*} p \leq 0.05$. 
practices.

\subsubsection{Age Differences in Students' Perceptions towards Learning Practices}

An Independent t-test was employed to determine age differences in students' perceptions towards learning practices whereby the age of students was used as an independent variable and the learning practices were treated as dependent variables. The results of the Independent t-test are presented in Table 6.

Table 6 showed a significant age difference in students' perception towards only one learning practice: studying practices $(\mathrm{t}=2.527, p=0.012)$. Further, the mature students ( $\geq 25$ years) perceived studying practices significantly higher ( $M$ $=3.36 ; \mathrm{SD}=0.710)$ as compared to the young students with age up to 24 years $(\mathrm{M}=3.23 ; \mathrm{SD}=0.446)$. It indicated that mature students are more conscious in their studying practices as compare to the young students. Therefore, young students may need motivation to improve on their study practices to enhance their learning.

\subsubsection{Faculty Differences in Students' Perceptions towards Learning Practices}

A One Way Analysis of Variance was conducted to determine faculty differences in students' perceptions towards learning practices whereby learning practices were considered as dependent variables and faculties as independent variables. The results of Analysis of variance are presented in Table 7.

Table 6. Age difference in students' perceptions towards the learning practices $(n=290)$.

\begin{tabular}{|c|c|c|c|c|c|}
\hline \multirow{2}{*}{ Age } & \multicolumn{5}{|c|}{ Classroom practices } \\
\hline & $n$ & $M$ & $S D$ & $t$ & $p$ \\
\hline$\leq 24$ years & 147 & 3.93 & 0.400 & & \\
\hline$\geq 25$ years & 143 & 4.03 & 0.418 & 1.918 & 0.056 \\
\hline Overall & 290 & 3.98 & 0.411 & & \\
\hline Age & \multicolumn{5}{|c|}{ Assessment practices } \\
\hline$\leq 24$ years & 147 & 3.75 & 0.602 & & \\
\hline$\geq 25$ years & 143 & 3.76 & 0.562 & 0.102 & 0.918 \\
\hline Overall & 290 & 3,76 & 0.581 & & \\
\hline Age & \multicolumn{5}{|c|}{ Studying practice } \\
\hline$\leq 24$ years & 147 & 3.23 & 0.447 & & \\
\hline$\geq 25$ years & 143 & 3.36 & 0.424 & 2.527 & $0.012^{*}$ \\
\hline Overall & 290 & 3.29 & 0440 & & \\
\hline Age & \multicolumn{5}{|c|}{ Academic integrity } \\
\hline$\leq 24$ years & 147 & 3.58 & 0.813 & & \\
\hline$\geq 25$ years & 143 & 3.68 & 0.710 & 1.132 & 0.258 \\
\hline Overall & 290 & 3.63 & 0764 & & \\
\hline
\end{tabular}

${ }^{*} p \leq 0.05$. 
Table 7. Faculty differences in students' perceptions towards the learning practices $(n=300)$.

\begin{tabular}{|c|c|c|c|c|c|}
\hline \multirow{2}{*}{ Faculty } & \multicolumn{5}{|c|}{ Classroom practices } \\
\hline & $N$ & $M$ & $S D$ & $F$ & $p$ \\
\hline Agriculture & 30 & 4.01 & 0.515 & \multirow{8}{*}{1.280} & \multirow{8}{*}{0.268} \\
\hline Education & 79 & 3.97 & 0.425 & & \\
\hline Health Sciences & 25 & 4.09 & 0.416 & & \\
\hline Humanities & 23 & 4.00 & 0.375 & & \\
\hline Law & 20 & 3.92 & 0.365 & & \\
\hline Science and Technology & 19 & 3.75 & 0.462 & & \\
\hline Social Science & 104 & 3.98 & 0.407 & & \\
\hline Overall & 300 & 3.97 & 0.424 & & \\
\hline \multirow{2}{*}{ Faculty } & \multicolumn{5}{|c|}{ Assessment practices } \\
\hline & $N$ & $M$ & $S D$ & $F$ & $p$ \\
\hline Agriculture & 30 & 3.78 & 0.590 & \multirow{8}{*}{4.540} & \multirow{8}{*}{$0.000^{*}$} \\
\hline Education & 79 & 3.90 & 0.517 & & \\
\hline Health Sciences & 25 & 3.50 & 0.420 & & \\
\hline Humanities & 23 & 3.57 & 0.602 & & \\
\hline Law & 20 & 3.48 & 0.669 & & \\
\hline Science and Technology & 19 & 3.47 & 0.673 & & \\
\hline Social Sciences & 104 & 3.88 & 0.572 & & \\
\hline Overall & 300 & 3.77 & 0.585 & & \\
\hline \multirow{2}{*}{ Faculty } & \multicolumn{5}{|c|}{ Studying practices } \\
\hline & $N$ & $M$ & $S D$ & $F$ & $p$ \\
\hline Agriculture & 30 & 3.46 & 0.353 & \multirow{8}{*}{3.710} & \multirow{8}{*}{$0.001^{*}$} \\
\hline Education & 79 & 3.38 & 0.408 & & \\
\hline Health Sciences & 25 & 3.22 & 0.423 & & \\
\hline Humanities & 23 & 3.45 & 0.469 & & \\
\hline Law & 20 & 3.10 & 0.326 & & \\
\hline Science and Technology & 19 & 3.04 & 0.339 & & \\
\hline Social Sciences & 104 & 3.25 & 0.484 & & \\
\hline Overall & 300 & 3.29 & 0.446 & & \\
\hline \multirow{2}{*}{ Faculty } & \multicolumn{5}{|c|}{ Academic integrity practices } \\
\hline & $N$ & $M$ & $S D$ & $F$ & $p$ \\
\hline Agriculture & 30 & 3.45 & 0.812 & \multirow{8}{*}{3.710} & \multirow{8}{*}{$0.001^{*}$} \\
\hline Education & 79 & 3.87 & 0.698 & & \\
\hline Health Sciences & 25 & 3.18 & 0.818 & & \\
\hline Humanities & 23 & 3.75 & 0.589 & & \\
\hline Law & 20 & 3.48 & 0.741 & & \\
\hline Science and Technology & 19 & 3.36 & 0.728 & & \\
\hline Social Sciences & 104 & 3.63 & 0728 & & \\
\hline Overall & 300 & 3.62 & 0.798 & & \\
\hline
\end{tabular}

${ }^{*} p \leq 0.05$. 
Table 7 showed significant faculty differences in the students' perceptions towards the three learning practices: assessment practices $(\mathrm{F}=4.54, p=0.000)$, studying practices $(\mathrm{F}=3.710, p=0.001)$ and academic integrity practices $(\mathrm{F}=$ $2.360, p=0.030$ ). Further, the students in education faculty had the highest differences towards assessment practices $(\mathrm{M}=3.90 ; \mathrm{SD}=0.517)$ while assessment practices were perceived the lowest by students in science and technology faculty $(\mathrm{M}=3.47 ; \mathrm{SD}=0.673)$. Table 7 further reflects that assessment practices are better organised in the education faculty as compared in the science and technology faculty. Thus, the science and technology faculty need to improve the assessment practices in order to improve the quality of learning. Students in the agriculture faculty had the highest differences towards studying practices $(\mathrm{M}=$ 3.46; $\mathrm{SD}=0.353$ ) while studying practices were perceived the lowest by students in the science and technology faculty $(\mathrm{M}=3.04 ; \mathrm{SD}=0.339)$. The studying practices adopted by the students in the agriculture faculty are better organised as compared to the students in the Science and Technology faculty. The students in the Science and Technology faculty need to improve on their studying practices to improve the quality of learning. Students in the education faculty had the highest differences towards academic integrity practices $(M=3.87$; $S D=0.698)$ while academic integrity practices were perceived the lowest by students in the Health faculty $(\mathrm{M}=3.18 ; 0.819)$. This situation reflects that academic practices are better organised in the education faculty as compared to the Health faculty. Thus, the science and technology faculty needs to improve on its academic integrity practices to improve the authenticity and quality of learning. These differences in students' perceptions of the assessment and studying practices can be argued through the fact that the course structure, contents and the learning pedagogies differ from faculty to faculty. The differences in the academic integrity practices raise one's eye brow as these practices are the backbone to maintaining the quality of learning. Further investigation needs to determine such differences in order to take appropriate measures to mitigate the gaps in the academic practices at the university.

\subsection{Differences in Students' Perceptions towards Pertinent Factors to Learning Practices}

Findings on the gender, age and faculty differences in students' perceptions towards factors pertinent to learning practices are presented in the subsections as follows.

\subsubsection{Gender Differences in Students' Perceptions towards Factors Pertinent to Learning Practices}

An Independent t-test was employed to determine gender differences in students' perceptions towards the factors that are pertinent to learning practices whereby students' gender was used as an independent variable and the factors pertinent to learning practices were treated as dependent variables. The results of the Independent $\mathrm{t}$-test are presented in Table 8. 
Table 8. Difference between male and female students' perceptions towards factors pertinent to learning practices $(n=296)$.

\begin{tabular}{cccccc}
\hline \multirow{2}{*}{ Gender } & \multicolumn{5}{c}{ Institutional factors } \\
\cline { 2 - 5 } & $\boldsymbol{n}$ & $\boldsymbol{M}$ & $\boldsymbol{S D}$ & $\boldsymbol{t}$ & $\boldsymbol{P}$ \\
\hline Female & 155 & 2.79 & 1.541 & \\
Male & 141 & 3.00 & 2.885 & 0.804 & 0.421 \\
Overall & 296 & 2.89 & 2.281 & \\
\hline Gender & & & Personal factors & \\
\hline Female & 155 & 3.33 & 0.527 & \\
Male & 141 & 3.18 & 0.583 & 2.358 \\
Overall & 296 & 3.26 & 0.559 & & \\
\hline
\end{tabular}

${ }^{*} p \leq 0.05$.

Table 8 shows a significant gender difference in students' perception towards personal factors affecting learning practices $(t=2.358, p=0.019)$ while the institutional factors pertinent to the learning practices were found to be insignificant $(\mathrm{t}=0.804, p=0.421)$. Further, female students perceived personal factors pertinent to learning significantly higher $(M=3.33$; $S D=0.527)$ as compared to their counterparts $(\mathrm{M}=3.18 ; \mathrm{SD}=0.583)$. It indicates that female students have more challenging personal factors in their learning as compared to the male students. Therefore, the personal factors can be explored further to enhance learning among the female students.

\subsubsection{Age Differences in Students' Perceptions towards Factors Pertinent to Learning Practices}

An Independent $\mathrm{t}$-test was employed to determine age differences of student in relation to their perceptions towards the factors pertinent to learning whereby the age of the students was used as an independent variable and the factors pertinent to learning were treated as dependent variables. The results of the Independent $\mathrm{t}$-test are presented in Table 9. Table 9 indicated that neither the young students ( $\leq 24$ years) nor the mature ones ( $\geq 25$ years) show significance in their perception towards the personal factors $(\mathrm{t}=1.755, p=0.080)$ and institutional factors pertinent to learning $(t=0.661, p=0.508)$. It reflected that personal and institutional factors pertaining to their learning are the same for the young and mature students.

\subsubsection{Faculty Differences in Students' Perceptions towards the Factors Pertinent to Learning Practices}

A One Way Analysis of Variance was employed to determine faculty differences in students' perceptions towards factors pertinent to learning practices. The students' responses to the factors pertinent to the learning practices were considered as the dependent variable and the faculties were used as the independent variables. The results of Analysis of Variance are presented in Table 10.

Table 10 showed a significant faculty difference in students' perception towards 
Table 9. Age difference in students' perceptions towards the factors pertinent to learning practices $(n=290)$.

\begin{tabular}{cccccc}
\hline & \multicolumn{5}{c}{ Institutional factors } \\
\cline { 2 - 6 } Age group & $\boldsymbol{n}$ & $\boldsymbol{M}$ & $\boldsymbol{S D}$ & $\boldsymbol{t}$ & $\boldsymbol{P}$ \\
\hline$\leq 24$ years & 147 & 2.81 & 1.561 & \\
$\geq 25$ years & 143 & 2.99 & 2.874 & 0.661 & 0.508 \\
Overall & 290 & 2.90 & 2.302 & \\
\hline Age group & & \multicolumn{5}{c}{ Personal factors } \\
$\leq 24$ years & 147 & 3.20 & 0.5775 & \\
$\geq 25$ years & 143 & 3.31 & 0.5288 & \multirow{2}{*}{1.755} & \\
Overall & 290 & 3.25 & 0.5560 & & \\
\hline
\end{tabular}

Table 10. Faculty differences in students' perceptions towards the factors pertinent to learning practices $(n=300)$.

\begin{tabular}{|c|c|c|c|c|c|}
\hline \multirow{2}{*}{ Faculty } & \multicolumn{5}{|c|}{ Institutional factors } \\
\hline & $n$ & $M$ & $S D$ & $F$ & $p$ \\
\hline Agriculture & 30 & 3.08 & 0.896 & \multirow{8}{*}{1.390} & \multirow{8}{*}{0.216} \\
\hline Education & 79 & 3.08 & 1.879 & & \\
\hline Health Sciences & 25 & 2.78 & 0.875 & & \\
\hline Humanities & 23 & 2.57 & 0.941 & & \\
\hline Law & 20 & 2.30 & 0.174 & & \\
\hline Science and Technology & 19 & 2.92 & 7.562 & & \\
\hline Social Sciences & 104 & 2.66 & 1.01 & & \\
\hline Overall & 300 & 2.89 & 2.26 & & \\
\hline Faculty & \multicolumn{5}{|c|}{ Personal factors } \\
\hline Agriculture & 30 & 3.29 & 0.443 & \multirow{8}{*}{2.360} & \multirow{8}{*}{$0.030^{*}$} \\
\hline Education & 79 & 3.39 & 0.574 & & \\
\hline Health Sciences & 25 & 3.20 & 0.471 & & \\
\hline Humanities & 23 & 3.42 & 0.532 & & \\
\hline Law & 20 & 3.30 & 0.520 & & \\
\hline Science and Technology & 19 & 3.06 & 0.534 & & \\
\hline Social Sciences & 104 & 3.15 & 0.586 & & \\
\hline Overall & 300 & 3.26 & 0.557 & & \\
\hline
\end{tabular}

${ }^{*} p \leq 0.05$.

personal factors pertinent to learning practices $(\mathrm{t}=2.360, p=0.030)$ while institutional factor were found to be insignificant $(\mathrm{t}=1.390, p=0.216)$. Personal factors differ from students to students and, it is obvious that the factors influence their learning practices differently. Among the seven faculties, students in the faculty perceived the personal factors the highest $(M=3.42$; $S D=0.532)$ 
while the students in Science and Technology faculty perceived them to be the lowest $(\mathrm{M}=3.06 ; \mathrm{SD}=0.534)$, indicating that the quality of students' learning in the Science and Technology faculty has a scope for improvement if the personal factors pertaining to learning are improved.

\section{Conclusion and Recommendations}

The study analysed gender, age and faculty differences in the perception of the undergraduates towards the various learning practices and pertinent factors at NUL. Four categories of learning practices: classroom practices, assessment practices, academic integrity practices, the studying practices and two factors (personal and institutional) pertinent to learning were analysed. Students perceived all the four learning practices above the mean level. Classroom practices and studying practices were perceived by the students to be the highest and lowest learning practices, respectively. Therefore, studying practices need to be improved further to boost the students' learning. Institutional factors were perceived to be lower than the mean level. This highlights the need to improve on the institutional factors in order to improve the learning practice among the students. Only academic integrity practice had a gender difference in students' perception while age difference was determined in studying practices. Female students perceived academic integrity practices as being higher than the male students, thus indicating that female students are perceived to have higher academic integrity as compared to the male students. No age difference in students' perception towards either the personal factors or institutional factor pertinent to learning was determined. This indicated that personal and institutional factors are the same for the young and the mature students.

Students in different faculties have perceived the three learning practices, assessment practices, studying practices and academic integrity practices, differently. The fact that students in the Science and Technology faculty perceive the studying and assessment practices as the lowest reflects that these two practices are poorly organised in the Science and Technology faculty. Thus, this faculty needs to improve on these practices in order to improve students' learning. Academic integrity practices are perceived as the lowest by students in the Health Sciences faculty. This indicates that this faculty also needs to improve on students' academic integrity practices in order to improve the authenticity of learning. The nature and type of integrity practices need to be investigated to institute appropriate measures to improve on the academic integrity practices at the university. Personal factors such as which are pertinent to the learning practices seem to lead to students' gender differences among the students while the institutional factors are found to have no gender differences. Further, female students perceive personal factors as being higher than the male students do. This indicates that female students face more challenging personal factors as compared to the male students. Therefore, exploring the personal factors can be helpful in enhancing learning among the female students. Personal factors pertinent to the 
learning practices are different among the students from the different faculties while institutional factors are found to be indifferent. As the students in the Science and Technology faculty perceive the learning practices and personal factors to be the lowest among the faculties at the university, it is recommended that studying practices and personal factors pertaining to students' learning need to be further investigated.

\section{Conflicts of Interest}

The authors declare no conflicts of interest regarding the publication of this paper.

\section{References}

Acharya, A. S., Prakash, A., Saxena, P., \& Nigam, A. (2013). Sampling: Why and How of It. Indian Journal of Medical Specialties, 4, 330-333.

https://doi.org/10.7713/ijms.2013.0032

Aguillon, S. M., Siegmund, G. F., Petipas, R. H., Drake, A. G., Cotner, S., \& Ballen, C. J. (2020). Gender Differences in Student Participation in an Active-Learning Classroom. CBE-Life Sciences Education, 19, 1-10. https://doi.org/10.1187/cbe.19-03-0048

Ah-Nam, L., \& Osman, K. (2017). Developing 21st Century Skills through a Constructivist-Constructionist Learning Environment. K-12 STEM Education, 3, 205-216.

Alzaghoul, A. F. (2012). The Implication of the Learning Theories on Implementing ELearning Courses. The Research Bulletin of Jordan ACM, 11, 27-30.

Areekkuzhiyil, S. (2019). Assessment Practices in Higher Education: Myths and Realities. University News, 57, 18-20.

Arquero, J. L., Fernandez-Polvillo, C., Hassall, T., \& Joyce, J. (2015). Vocation, Motivation and Approaches to Learning: A Comparative Study. Education and Training, 57, 13-30. https://doi.org/10.1108/ET-02-2013-0014

Asikainen, H., \& Gijbels, D. (2017). Do Students Develop towards More Deep Approaches to Learning during Studies? A Systematic Review on the Development of Students' Deep and Surface Approaches to Learning in Higher Education. Educational Psychology Review, 29, 205-234. https://doi.org/10.1007/s10648-017-9406-6

Baeten, M., Dochy, F., Struyven, K., Parmentier, E., \& Vanderbruggen, A. (2016). Student-Centred Learning Environments: An Investigation into Student Teachers' Instructional Preferences and Approaches to Learning. Learning Environments Research, 19, 43-62. https://doi.org/10.1007/s10984-015-9190-5

Balam, E. M. (2015). Learning Strategies and Motivation of Graduate Students: Is Gender a Factor. Institute for Learning Styles Journal, 1, 1-9.

Baliyan, S. P., \& Moorad, F. R. (2018). Teaching Effectiveness in Private Higher Education Institutions in Botswana: Analysis of Students' Perceptions. International Journal of Higher Education, 7, 143-155. https://doi.org/10.5430/ijhe.v7n3p143

Bhardwaj, P. (2019). Types of Sampling in Research. Journal of the Practice of Cardiovascular Sciences, 5, 157-163.

Black, P., \& Wiliam, D. (2018). Classroom Assessment and Pedagogy. Assessment in Education: Principles, Policy \& Practice, 25, 551-575. https://doi.org/10.1080/0969594X.2018.1441807

Børte, K., Nesje, K., \& Lillejord, S. (2020). Barriers to Student Active Learning in Higher 
Education. Teaching in Higher Education, 1-19. https://doi.org/10.1080/13562517.2020.1839746

Brau, B. (2020). Constructivism. In R. Kimmons, \& S. Caskurlu (Eds.), The Students' Guide to Learning Design and Research (pp. 33-43).

Brown, G. T. L., Kennedy, K. J., Fok, P. K., Chan, J. K. S., \& Yu, W. M. (2009). Assessment for Student Improvement: Understanding Hong Kong Teachers' Conceptions and Practices of Assessment. Assessment in Education: Principles, Policy \& Practice, 16, 347-363. https://doi.org/10.1080/09695940903319737

Bruns, B., \& Luque, J. (2014). Better Teachers for Latin America and the Caribbean: New Evidence on How to Raise Teacher Quality and Student Learning. World Bank. https://doi.org/10.1596/978-1-4648-0151-8 ch2

Cetin, B. (2016). Approaches to Learning and Age in Predicting College Students' Academic Achievement. Journal of College Teaching and Learning, 13, 21-28. https://doi.org/10.19030/tlc.v13i1.9568

Chaika, G. (2020). Psychological Characteristics Influencing Personal Autonomy as a Factor of Psychological Well-Being. Psychological Journal, 6, 18-28.

https://doi.org/10.31108/1.2020.6.1.2

Chang, B. (2018). Patterns of Knowledge Construction. Adult Education Quarterly, 68, 108136. https://doi.org/10.1177/0741713617751174

Chatterton, S. (2020). How do Young People Think They Learn? A Learning Theory Taxonomy Devised from Pupil Preferences, Cambridge Educational Research e-Journal, 7, 191-231.

Chen, S. C., Yang, S. J. H., \& Hsiao, C. C. (2016). Exploring Student Perceptions, Learning Outcome and Gender Differences in a Flipped Mathematics Course. British Journal of Educational Technology, 47, 1096-1112. https://doi.org/10.1111/bjet.12278

Corbin, A. (2017). Assessing Differences in Learning Styles: Age, Gender and Academic Performance at the Tertiary Level in the Caribbean. Caribbean Teaching Scholar, 7, 6791.

Creswell, J. W. (2017). Research Design: Qualitative, Quantitative, and Mixed Methods Approaches. Sage Publications.

Creswell, J. W., \& Creswell, J. D. (2017). Research Design: Qualitative, Quantitative, and Mixed Methods Approaches. Sage Publications.

Croy, S. R. (2018). Development of a Group Work Assessment Pedagogy Using Constructive Alignment Theory. Nurse Education Today, 6, 49-53.

https://doi.org/10.1016/j.nedt.2017.11.006

Derry, J. (2018). Knowledge in Education: Why Philosophy Matters. An Inaugural Professorial Lecture. UCL Institute of Education Press.

Dlouhá, J., \& Pospíšilová, M. (2018). Education for Sustainable Development Goals in Public Debate: The Importance of Participatory Research in Reflecting and Supporting the Consultation Process in Developing a Vision for Czech Education. Journal of Cleaner Production, 172, 4314-4327. https://doi.org/10.1016/j.jclepro.2017.06.145

Duff, A., \& Mladenovic, R. (2015). Antecedents and Consequences of Accounting Students' Approaches to Learning: A Cluster Analytic Approach. The British Accounting Review, 47, 321-338. https://doi.org/10.1016/j.bar.2014.06.003

Duy, N. B. P., Binh, L. C., \& Giang, N. T. P. (2021). Factors Affecting Students' Motivation for Learning at the Industrial University of Ho Chi Minh City. In K. Arai, S. Kapoor, \& R. Bhatia (Eds.), Proceedings of the Future Technologies Conference (pp. 239-262). Springer. https://doi.org/10.1007/978-3-030-63089-8 15 
Eddy-Spicer, D., Ehren, M., Bangpan, M., Khatwa, M., \& Perrone, F. (2016). Under What Conditions Do Inspection, Monitoring and Assessment Improve System Efficiency, Service Delivery and Learning Outcomes for the Poorest and Most Marginalised? A Realist Synthesis of School Accountability in Low- and Middle-Income Countries. Social Science Research Unit, UCL Institute of Education, University College London.

Ellis, R. A., \& Bliuc, A. M. (2019). Exploring New Elements of the Student Approaches to Learning Framework: The Role of Online Learning Technologies in Student Learning. Active Learning in Higher Education, 20, 11-24.

https://doi.org/10.1177/1469787417721384

Ertmer, P. A., \& Newby, T. J. (2013). Behaviorism, Cognitivism, and Constructivism: Comparing Critical Features from an Instructional Design perspective. Performance Improvement Quarterly, 26, 43-71. https://doi.org/10.1002/piq.21143

Evans, D. K., \& Popova, A. (2016). What Really Works to Improve Learning in Developing Countries? An Analysis of Divergent Findings in Systematic Reviews. The World Bank Research Observer, 31, 242-270. https://doi.org/10.1093/wbro/lkw004

Hailkari, T., Virtanen, V., Vesalainen, M., \& Postareff, L. (2021). Student Perspectives on How Different Elements of Constructive Alignment Support Active Learning. Active Learning in Higher Education, 1-15. https://doi.org/10.1177/1469787421989160

Henderson, M., Selwyn, N., \& Aston, R. (2017). What Works and Why? Student Perceptions of 'Useful' Digital Technology in University Teaching and Learning. Studies in Higher Education, 42, 1567-1579. https://doi.org/10.1080/03075079.2015.1007946

Iannone, P., Czichwsky, C., \& Ruf, J. (2020). The Impact of High Stakes Oral Performance Assessment on Students' Approaches to Learning: A Case Study. Educational Studies in Mathematics, 103, 313-337. https://doi.org/10.1007/s10649-020-09937-4

Jaiwal, P. (2019). Using Constructive Alignment to Foster Teaching Learning Processes. English Language Teaching, 12, 10-23. https://doi.org/10.5539/elt.v12n6p10

Khong, H. K., Hassan, N. H., \& Ramli, N. (2017). Motivation and Gender Differences in Learning Spanish as a Foreign Language in a Malaysian Technical University. Malaysian Journal of Learning and Instruction, 14, 59-83. https://doi.org/10.32890/mjli2017.14.2.3

Kington, A., Regan, E., Sammons, P., \& Day, C. (2012). Effective Classroom Practice: A Mixed-Method Study of Influences and Outcomes: A Research Paper. The Nottingham Jubilee Press, School of Education, University of Nottingham.

Li, Y., \& Oliveira, H. (2015) Research on Classroom Practice. In S. Cho (Ed.), The Proceedings of the 12th International Congress on Mathematical Education (pp. 489-496). Springer. https://doi.org/10.1007/978-3-319-12688-3 46

Lumpkin, A., Achen, R. M., \& Dodd, R. K. (2015). Student Perceptions of Active Learning. College Student Journal, 49, 121-133.

Mahmud, M., \& Nur, S. (2018). Exploring Students' Learning Strategies and Gender Differences in English Language Teaching. International Journal of Language Education, 2, 51-64. https://doi.org/10.26858/ijole.v2i1.4346

Marton, F., \& Saljo, R. (1976). On Qualitative Differences in Learning: Outcome and Process. British Journal of Educational Psychology, 46, 4-11. https://doi.org/10.1111/j.2044-8279.1976.tb02980.x

Mokhethi, M. C., Malunga, M. M. J., \& Thetsane, R. M. (2019). Student's Satisfaction Dimensions Contributing to Overall Satisfaction at the National University of Lesotho. Review of Contemporary Business Research, 8, 1-11.

Nardi, P. M. (2018). Doing Survey Research: A Guide to Quantitative Methods. Routledge. 
https://doi.org/10.4324/9781315172231

NUL (2015). National University of Lesotho's Strategic Plan 2015-2020. National University of Lesotho.

NUL (2018). NUL-CHE Report of 18 April, 2018. National University of Lesotho.

Nurna, D. N., \& Rudi, W. (2020). Factors Affecting the Learning Spirit of Students. Russian Journal of Agricultural and Socio-Economic Sciences, 99, 18-28.

O’Leary, M., \& Wood, P. (2019). Reimagining Teaching Excellence: Why Collaboration, Rather than Competition, Holds the Key to Improving Teaching and Learning in Higher Education. Educational Review, 71, 122-139. https://doi.org/10.1080/00131911.2019.1524203

Omodan, B. I. (2019). Democratic Pedagogy in South Africa: A Rethinking Viewpoint for Knowledge Construction. Journal of Social Studies Education Research, 10, 188-203.

Parpala, A., Lindblom-Ylänne, S., Komulainen, E., Litmanen, T., \& Hirsto, L. (2010). Students' Approaches to Learning and Their Experiences of the Teaching-Learning Environment in Different Disciplines. British Journal of Educational Psychology, 80, 269282. https://doi.org/10.1348/000709909X476946

Picton, C., Kahu, E. R., \& Nelson, K. (2018). "Hardworking, Determined and Happy”: FirstYear Students' Understanding and Experience of Success. Higher Education Research \& Development, 37, 1260-1273. https://doi.org/10.1080/07294360.2018.1478803

Pinto, G., Bigozzi, L., Vettori, G., \& Vezzani, C. (2018). The Relationship between Conceptions of Learning and Academic Outcomes in Middle School Students According to Gender Differences. Learning, Culture and Social Interaction, 16, 45-54. https://doi.org/10.1016/j.lcsi.2017.11.001

Poondej, C., \& Lerdpornkulrat, L. (2016). Relationship between Motivational Goal Orientations, Perceptions of General Education Classroom Learning Environment, and Deep Approaches to Learning. Kasetsart Journal of Social Sciences, 37, 100-103. https://doi.org/10.1016/j.kjss.2015.01.001

Postareff, L., Mattson, M., \& Parpala, A. (2018). The Effect of Perceptions of the TeachingLearning Environment on the Variation in Approaches to Learning-Between-Student Differences and Within-Student Variation. Learning and Individual Differences, 68, 96-107. https://doi.org/10.1016/j.lindif.2018.10.006

Richardson, J. T. E. (2013). Approaches to Studying across the Adult Life Span: Evidence from Distance Education. Learning and Individual Differences, 26, 74-80. https://doi.org/10.1016/j.lindif.2013.04.012

Saar, E., Täht, K., \& Roosalu, T. (2014). Institutional Barriers for Adults' Participation in Higher Education in Thirteen European Countries. Higher Education, 68, 691-710. https://doi.org/10.1007/s10734-014-9739-8

Sinclair, J., \& Aho, A. M. (2018). Experts on Super Innovators: Understanding Staff Adoption of Learning Management Systems. Higher Education Research \& Development, 37, 158-172. https://doi.org/10.1080/07294360.2017.1342609

Sotiriadou, P., Logan, D., Daly, A., \& Guest, R. (2020). The Role of Authentic Assessment to Preserve Academic Integrity and Promote Skill Development and Employability. Studies in Higher Education, 45, 2132-2148. https://doi.org/10.1080/03075079.2019.1582015

Spiegel, S. J. (2020). Visual Storytelling and Socio-Environmental Change: Images, Photographic Encounters, and Knowledge Construction in Resource Frontiers. Annals of the American Association of Geographers, 110, 120-144.

https://doi.org/10.1080/24694452.2019.1613953 
Taber, K. S. (2018). The Use of Cronbach's Alpha When Developing and Reporting Research Instruments in Science Education. Research in Science Education, 48, 1273-1296. https://doi.org/10.1007/s11165-016-9602-2

Tight, M. (2014). Discipline and Theory in Higher Education Research. Research Papers in Education, 29, 93-110. https://doi.org/10.1080/02671522.2012.729080

Tlali, T. (2019a). Continuing Professional Development of Lecturers at the National University of Lesotho: Challenges and Milestones. International Journal of African Higher Education, 5, 107-121. https://doi.org/10.6017/ijahe.v5i1.10966

Tlali, T. (2019b). Creating an Environment That Nurtures Deep Learning: How Does the National University of Lesotho Fare? Independent Journal of Teaching and Learning, 14, 19-31.

Tlali, T., \& Jacobs, L. (2015). Teaching and Assessment Practices at the National University of Lesotho: Some Critical Comments. Bulgarian Comparative Education Society.

Toylan, N., Semerciöz, F., \& Hassan, M. (2020). Knowledge Sharing in Strategic Alliance Relationships: An Empirical Research on Hotels in Turkey. European Journal of Tourism Research, 24, 2403-2403.

Uiboleht, K., Karm, M., \& Postareff, L. (2018). The Interplay between Teachers' Approaches to Teaching, Students' Approaches to learning And Learning Outcomes: A Qualitative Multi-Case Study. Learning Environment Research, 21, 321-347. https://doi.org/10.1007/s10984-018-9257-1

Van Kesteren, M. T. R., \& Meeter, M. (2020). How to Optimize Knowledge Construction in the Brain? Science of Learning, 5, Article No. 5.

https://doi.org/10.1038/s41539-020-0064-y

Vermunt, J. D., \& Donche, V. (2017). A Learning Patterns Perspective on Student Learning in Higher Education: State of the Art and Moving Forward. Educational Psychology Review, 29, 269-299. https://doi.org/10.1007/s10648-017-9414-6

Wahlheim, C. N., McDaniel, M. A., \& Little, J. L. (2016). Category Learning Strategies in Younger and Older Adults: Rule Abstraction and Memorization. Psychology and Aging, 31, 346-357. https://doi.org/10.1037/pag0000083

Webber, K. L. (2012). The Use of Learner-Centered Assessment in US Colleges and Universities. Research in Higher Education, 53, 201-228.

https://doi.org/10.1007/s11162-011-9245-0

White, P. J., Larson, I., Styles, K., Yuriev, E., Evans, D. R., Rangachari, P. K. et al. (2016). Adopting an Active Learning Approach to Teaching in a Research-Intensive Higher Education Context Transformed Staff Teaching Attitudes and Behaviours. Higher Education Research \& Development, 35, 619-633. https://doi.org/10.1080/07294360.2015.1107887

Wongwatkit, C., Panjaburee, P., Srisawadsi, N., \& Seprum, P. (2020). Moderating Effects of Gender Differences on the Relationships between Perceived Learning Support, Intention to Use, and Learning Performance in a Personalized E-Learning. Journal of Computer Education, 7, 22-255. https://doi.org/10.1007/s40692-020-00154-9

Zhao, Y., Kuan, H. K., Chung, J. O. K., Chan, C. K. Y., \& Li, W. H. C. (2018). Students' Approaches to Learning in a Clinical Practicum: A Psychometric Evaluation Based on Item Response Theory. Nurse Education Today, 66, 179-186.

https://doi.org/10.1016/j.nedt.2018.04.015 